\title{
Fibroma: case report
}

\author{
Fibroma: relato de caso
}

Fibroma: reporte de un caso

\author{
Natália Aline Ricci SABINO ${ }^{1}$ \\ Ellen Cristina GAETTI-JARDIM ${ }^{2}$ \\ Elerson GAETTI-JARDIM JÚNIOR ${ }^{3}$ \\ Rosana Leite de MELO4 \\ ${ }^{I}$ Especalist Patients Special University Hospital of the Federal University of Mato Grosso do Sul, UFMS, Campo Grande-MS, Brazil \\ ${ }^{2}$ Coordinator of Residence in Patients Critics of the University Hospital of the Federal University of Mato Grosso do Sul, \\ UFMS, Campo Grande-MS, Brazil \\ Adjunct Professor of Oral and Maxillofacial Surgery, of the Federal University of Mato Grosso do Sul, UFMS, Campo Grande-MS, Brazil \\ ${ }^{4}$ Titular Professor of Microbiology, Pathology and Propaedeutical Clinical Department of Araçatuba Dental School \\ UNESP-Univ Estadual Paulista, Araçatuba-SP, Brazil \\ ${ }^{4}$ Professor of Semiology at the Faculty of Medicine of the Federal University of Mato Grosso do Sul, UFMS, Campo Grande-MS, Brazil
}

\begin{abstract}
Fibroma is a common injury in the oral mucosa, considered a reactive hyperplasia of connective tissue in response to constant trauma to the oral mucosa is dental order or not, is a noninfectious lesion benign fibrous connective tissue, with a predilection for females and between the fourth and sixth decades of life and are usually situated in the inner portion of the lower lip, tongue and buccal mucosa. They are usually nodular, firm palpation, asymptomatic and coloring similar to the adjacent mucosa, sessile base, smooth surface. Routine treatment is conservative surgical excision. This paper reports a clinical case of irritation fibroma in the oral mucosa of large patient ratios male, young and constant trauma history in the region, as well as dental crowding near pathology. Such fibroma was treated surgically and with remission of awareness of the deleterious habits oral mucosa to prevent the recurrence of the lesion.
\end{abstract}

Descriptors: Fibroma; Diagnosis; Therapeutics.

\section{Resumo}

Fibroma é uma lesão comum na mucosa bucal, considerada uma hiperplasia do tecido conjuntivo em resposta ao trauma constante da mucosa bucal, de ordem dentária ou não. Trata-se de lesão não infecciosa e benigna do tecido conjuntivo fibroso, com predileção pelo gênero feminino e entre a quarta e sexta década de vida. A lesão geralmente se situa na parte interna da porção inferior do lábio, língua e mucosa bucal. Mostra-se geralmente nodular, base séssil, superfície lisa. firme à palpação, assintomática e com coloração semelhante à mucosa adjacente, O tratamento de rotina é a excisão cirúrgica conservadora. Este artigo relata um caso clínico de fibroma de grandes proporções de paciente jovem do gênero masculino, com história de trauma constante na região, bem como apinhamento dentário próximo à patologia. Tal fibroma foi tratado cirurgicamente e com participação consciente do paciente para remissão dos hábitos deletérios mucosa para prevenir a recorrência da lesão.

Descritores: Fibroma; Diagnóstico; Terapêutica.

\section{Resumen}

Fibroma es una lesión común a la mucosa oral, considerada una hiperplasia en respuesta a la constante trauma del tejido de la mucosa oral y de origen dental o no. No es lesión infecciosa y benignos de tejido conectivo fibroso, con predilección por las hembras y entre la cuarta y sexta década de la vida. La lesión generalmente se encuentra dentro de la parte inferior de los labios, lengua y mucosa oral. Se muestra la base sésil generalmente nodular, superficie lisa. firme a la palpación, asintomático y de color similar a la mucosa adyacente, el tratamiento habitual es la extirpación quirúrgica conservadora. En este artículo se reporta un caso de grandes proporciones fibroides del paciente varón joven con historia de trauma constante en la región, así como el hacinamiento, cerca de la patología. Tal fibroma fue tratado quirúrgicamente y participación consciente del paciente hasta la remisión de los hábitos nocivos mucosa para prevenir la recurrencia de la lesión.

Descriptores: Fibroma; Diagnóstico; Terapéutica. 


\section{INTRODUCTION}

The fibroma is the most common volumetric increase of the buccal cavity sometimes mistaken as a reactive hyperplasia and not as an isolated entity, and may receive a number of denominations as traumatic fibroma, fibrous hyperplasia, oral irritated fibroma, fibrous hyperplasia located and fibroepithelial polyp ${ }^{1}$.

It can occur anywhere in the mouth with the most common location for the oral mucosa, along the line of occlusion probably caused by deleterious habit like chewing, overhanging dental restorations or overextended flanges of dentures, leading to excessive growth of fibroblasts and collagen resulting in a submucosal with evident increase of a painless mass ${ }^{2}$.

Clinically, the lesion presented as an aspect of nodular lesions similar to the adjacent mucosa, which may appear to be grayish-brown in black patients. Sessile nature and may measure $\mathrm{mm}$ to $1.5 \mathrm{~cm}$ in its greatest extent.

They are usually asymptomatic, unless there is ulceration on its surface because of the constant habit of biting the region. They are more common in the fourth to sixth decade of life, affecting more women than men at a ratio of $2: 1^{3}$.

Treatment irritation fibroma is based on conservative surgical excision; Recurrences are rare since the causal factor is also eliminated ${ }^{4}$.

\section{CASE REPORT}

Patient 17 year old male presented to consultation with volume up complaint in the mouth with a history of 2 years of evolution, having painful symptomatology, smoker for 3 years (10 cigarettes per day), denies recent hospitalizations, denies systemic comorbidity, but with the habit of nibbling the oral mucosa and lips for many years.

Clinical examination lesion with nodular mass aspect, single, pedunculated, and fibrous consistency located in jugal mucosa left with about $5 \mathrm{~cm}$ in its greatest extent, stretching to lip region this presenting whitish area with predominance in intra oral region point occlusion of the upper and lower dental elements, denoting constant trauma leading to formation of two ulcers of approximately $3 \mathrm{~mm}$ in length. He had no lymphadenopathy, and painful symptomatology (Figures 1 and 2).

Performed excisional biopsy, fixed piece in $10 \%$ formalin and sent to the pathology service. So with reactive fibro-epithelial hyperplasia report with ulceration covered area by fibrinous cap, with no morphologic evidence of malignancy (Figure 3).

\section{DISCUSSION}

The irritation is still in the region as well as denoted in the literature can make the bed of the offwhite injury as in the case presented, by virtue also of the exaggerated size of the fibroma concerned this fact is of importance injury herein because not $15 \mathrm{~cm}$ reported in the literature but an injury exaggerated dimensions hitherto little knowledge had in the literature ${ }^{3}$.

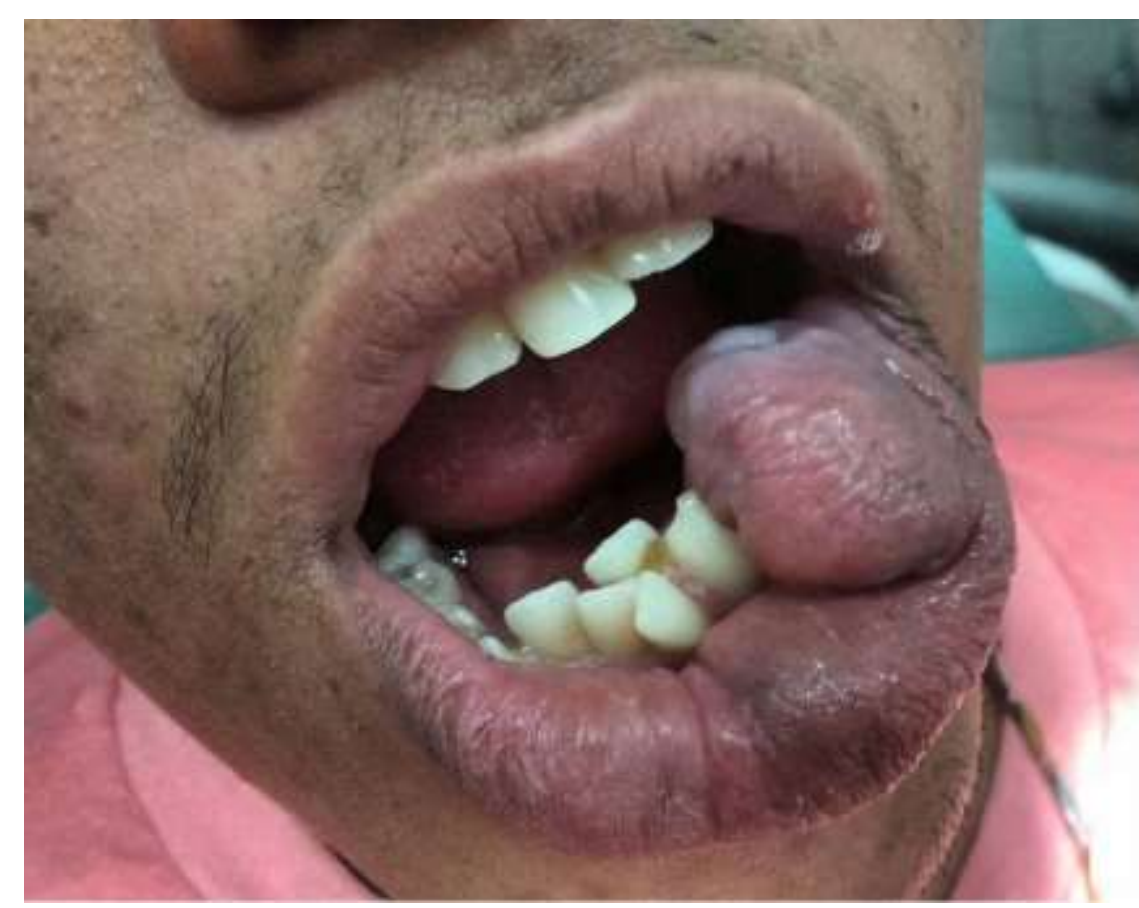

Figure 1. Extensive lesions in the oral mucosa, preventing power of the patient, occlusion and mouth closure

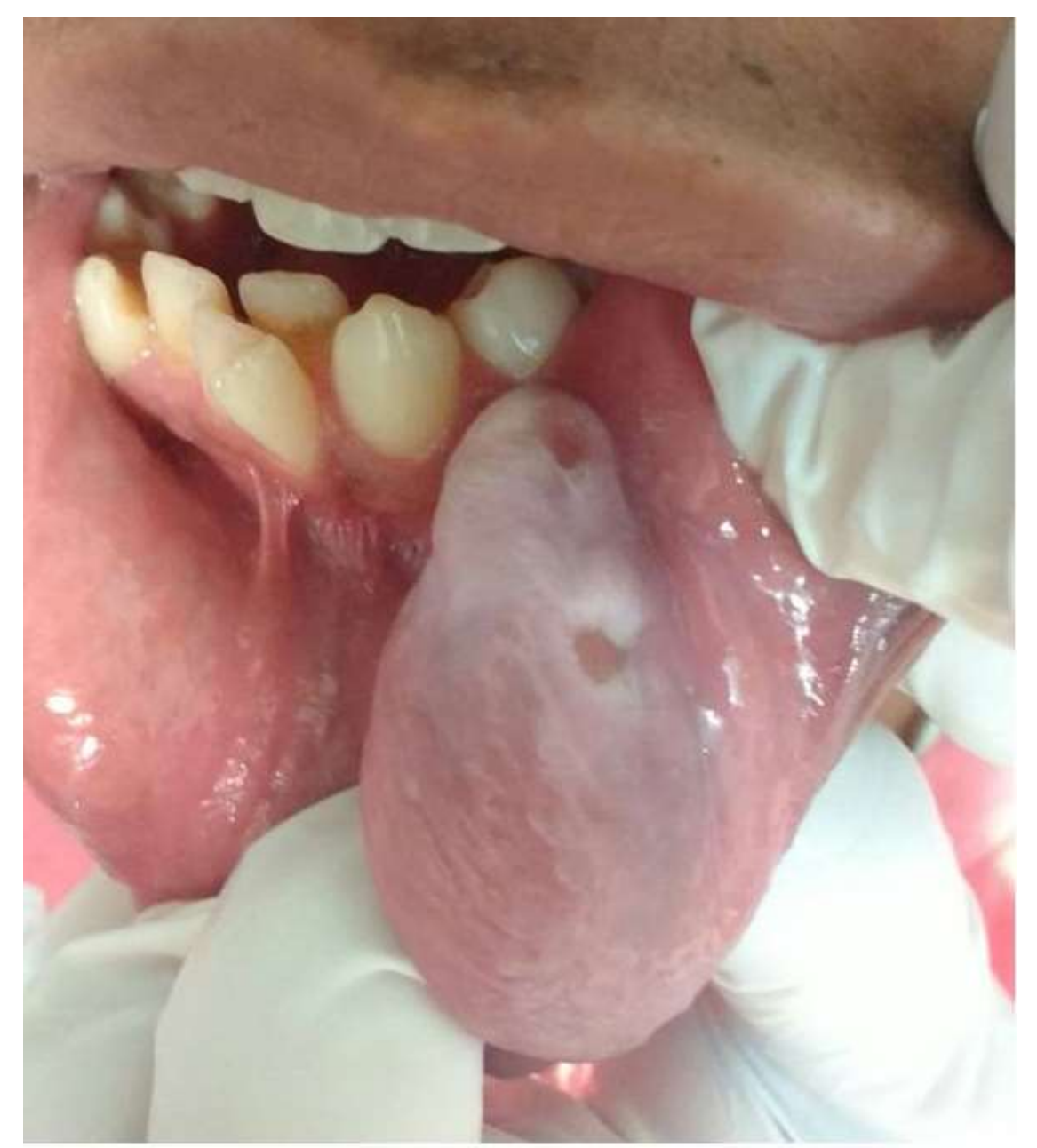

Figure 2. Presence scoring bites in an attempt to occlusal of the patient, presence of teeth crowding

Fibroma by being reactive and everyday injuries in daily life of Stomatological, depending on their characteristics, can be diagnosed as other diseases from hyperplasia or papillomas and hemangiomas as described by Regezi et al. ${ }^{5}$, which sets up mainly with what was exposed, the surgical removal treatment of the injury associated imperatively removal of the causative agent, thus avoiding the remission of the disease. 


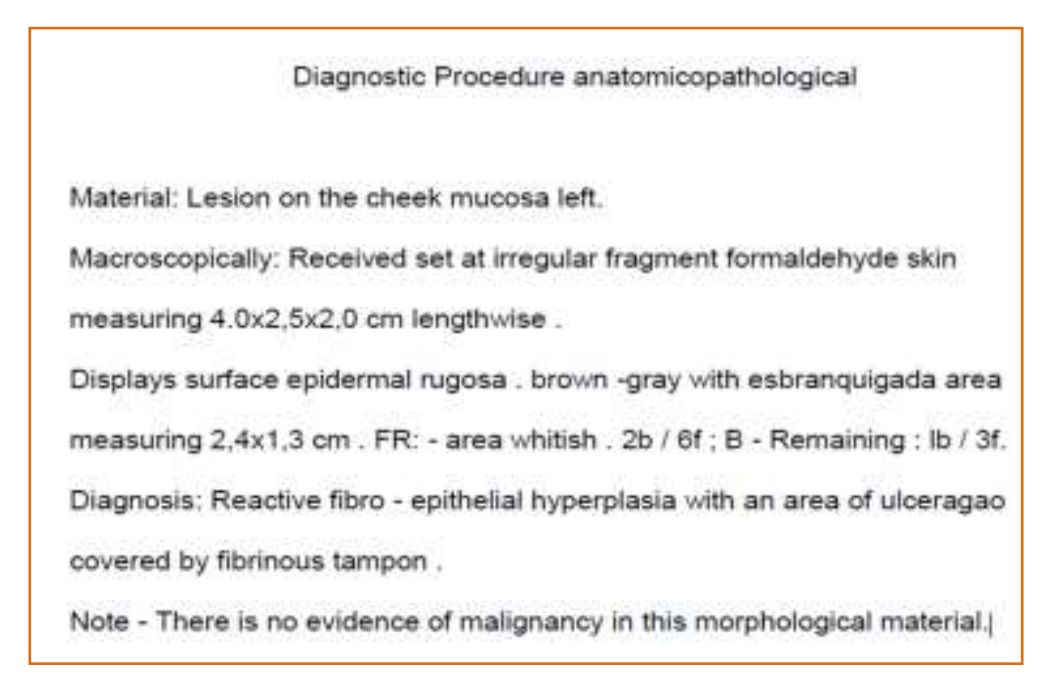

Figure 3. Histopathological Report revealed suggestive finds of chronic inflammatory fibrous hyperplasia no signs of malignancy

Unlike the literature that mentions the presence of fibroma in middle-aged people ${ }^{6}$ in this case the patient was young and there are at least two years has the habit of biting the oral mucosa which infers tell us that the time evolution of injury is much higher than that besides the possibility of tooth movement as shown in the pictures due to malocclusion of the patient, the inability to occlude because of the lesion interposed between the arches.

The final diagnosis was not provided only by the clinical findings especially the presence of constant trauma which led us to the primary diagnosis of irritation fibroma by the common location of it even in size exacerbated but also by histopathology, as corroborated by the findings of ${ }^{7,8}$.

Fibroma is more often found in adult patients in the oral mucosa as a result of constant irritation of the soft tissue, a fact observed in the present case, which differs from the others is that the patient could barely close his mouth without touching the injury. Thus the lesion was treated by complete resection that has advantages, such as the removal of the entire lesion to deliver biological material for histopathology examination, and eliminates the inconvenience that was caused to the patient and the possibility of correction and dental leveling changed possibly exacerbated by the size of pathology ${ }^{8}$.

\section{CONCLUSION}

Even in the large excisional surgery was the best course to take for the case presented. There was no recurrence of injury to date, which sets us how successful the case, necessitating long-term treatment towards patient the patient's awareness to avoid habits that characterize the return to arising of reactive lesions as mentioned.

\section{REFERENCES}

1. Barker DS, Lucas BR. Localized fibrous overgrowths of the oral mucosa. Br J Oral Surg. $1967 ; 5: 86-92$.
2. Mandel L, Baurmash H. Irritation Fibroma report of a case. Jour Dentistry. 2001; 9(36):344-7

3. Neville BW, Damm DD, Allen CM. Bouquot J. Oral and Maxillofacial Pathology, 3rd Edition. 2009.

4. Toida M, Murakami $\mathrm{T}$, Kato $\mathrm{K}$ et al. Irritation fibroma of the oral mucosa: a clinicopathological study of 129 lesions in 124 cases. Oral Med Pathol. 2001; 6:91-94.

5. Regezi JA, Sciubba JJ, Richard K. Oral Pathology: Clinical Pathologic Correlations. 5th ed. Philadelphia: Saunders Elsevier; 2008.

6. Pupo MM, Isla DV, Garrido MOR, et al., Presentación de un paciente con fibroma traumático subyacente a prótesis dental. CCM. 2013; 17(4):523-527.

7. Laskaris G. Color atlas of oral diseases in children and adolescents. New York: Thieme Medical Publishers Inc., 2000.

8. Valério RA, Queiroz AM, Romualdo PC, et al. Mucocele and Fibroma: Treatment and Clinical Features for Differential Diagnosis. Braz Dent J. 2013; 24(5): 537-41.

\section{CONFLICTS OF INTERESTS}

The authors declare no conflicts of interests.

\section{CORRESPONDING AUTHOR}

Ellen Cristina Gaetti-Jardim

ellengaetti@gmail.com 